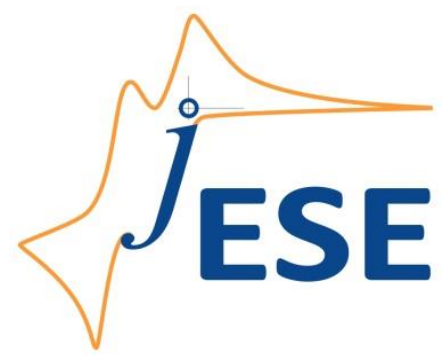

Open Access: ISSN 1847-9286

www.jESE-online.org

Original scientific paper

\title{
Study of electrochemical deposition of Ni-Mo thin films from alkaline electrolytes
}

\author{
Ulviyya Magsud Gurbanova ${ }^{1, \bigotimes}$, Dunya Mahammad Babanly ${ }^{1,2}$, \\ Ruhangiz Gurmuz Huseynova ${ }^{1}$ and Dilgam Babir Tagiyev ${ }^{1}$ \\ ${ }^{1}$ Institute of Catalysis and Inorganic Chemistry named after acad. M. Nagiyev, Azerbaijan National \\ Academy of Sciences, AZ 1143, Baku, H. Javid 113, Azerbaijan \\ ${ }^{2}$ French Azerbaijani University (UFAZ), AZ1010, Baku, Nizami 189, Azerbaijan
}

Corresponding author: ${ }^{\circledR}$ uqurbanova92@gmail.com, phone: +994702756030

Received: October 7, 2020; Revised: December 4, 2020; Accepted: December 5, 2020

\begin{abstract}
The process of co-deposition of Ni with Mo from alkaline electrolytes was studied by taking linear and cyclic polarization curves of Pt electrode at various concentrations of initial components and potential scan rates. Solutions of $\mathrm{Na}_{2} \mathrm{MoO}_{4} \cdot 2 \mathrm{H}_{2} \mathrm{O}$ and $\mathrm{NiSO}_{4} \cdot 7 \mathrm{H}_{2} \mathrm{O}$ were used as sources of ions of the main components in $\mathrm{NH}_{4} \mathrm{OH}$ electrolyte. It was found that codeposition of nickel with molybdenum goes through the oxide formation stage, and a solid solution of these two metals is deposited on the cathode surface. The film obtained at the constant current on Ni electrode under optimal conditions was found amorphous, but additional thermal treatment at $500{ }^{\circ} \mathrm{C}$ for one hour made it polycrystalline. This was confirmed by peaks in X-ray diffraction pattern, corresponding to $\mathrm{NiMoO}_{4}, \mathrm{Ni}$, and $\mathrm{MoO}_{3}$. The proposed electrolyte and electrolysis conditions allow to obtain thin films with molybdenum content ranging from 17.1 to 50.9 at.\%. The co-deposition of Ni with Mo is limited by diffusion of these ions to the cathode surface. The knowledge of the mechanism of co-deposition of $\mathrm{Ni}$ and Mo will make possible the selection of optimal conditions for deposition of alloys of the required composition with satisfactory electrocatalytic properties.
\end{abstract}

\section{Keywords}

$\mathrm{Ni}$-Mo co-deposition, electrodeposition, potentiodynamic polarization, ammonium hydroxide, platinum substrate, nickel substrate

\section{Introduction}

Nickel-molybdenum alloys have multifunctional properties, and their catalytic activity in the hydrogen evolution process is one of the most studied topics in the literature [1-3]. Ni-Mo alloys can be obtained by several methods among which metallurgical ones are not convenient due to easy 
oxidation and high melting point of molybdenum. Powder metallurgy and mechanical alloying [4], spark plasma sintering [5], and laser sintering [6] are actual methods, widely used to obtain Ni-Mo alloys. All these methods, however, are expensive in comparison with the electrochemical synthesis of Ni-Mo alloys. Obtaining of molybdenum alone by electrodeposition from aqueous solutions is very difficult, what can be facilitated by its co-deposition with metals of the iron group ( $\mathrm{Fe}, \mathrm{Ni}, \mathrm{Co})$, i.e. in the presence of one of these components.

When studying the co-deposition of two metals, it would be necessary to study their behavior separately in the same electrolyte, and record deposition polarization curves of each metal under the same conditions. The electrodeposition of molybdenum from tartrate electrolytes was studied in [7], and from alkaline electrolytes in [8]. Deposition of nickel from an alkaline citrate electrolyte was studied in [9], and from an alkaline electrolyte in [10]. Although nickel possesses electrocatalytic properties and due to these properties is often used in industry, the overvoltage of hydrogen evolution (HER) on the nickel electrode is quite high. This causes an increase in the energy consumption during its use. In order to reduce overvoltage, nickel is often doped with other elements such as Mo [11], Co [12], P [13], Cu [14], and some others. Besides, the results of water electrolysis on titanium and molybdenum electrodes from neutral $(\mathrm{NaCl})$ and alkaline $(\mathrm{NaOH})$ electrolytes showed that addition of $\mathrm{Mo}(\mathrm{VI})$ ions into the electrolyte has activated HER [15]. At high polarization, Mo-containing films were formed at the cathode by electroreduction of Mo (VI) ions. Presence of Mo-containing film reduces the overvoltage for HER and increases the electrode activity, what is exclusively due to the catalytical activity of the deposited film [15].

A number of scientific works has already been devoted to the co-electrodeposition of Ni-Mo alloys. In their study of the mechanism of this process, Landolt and co-workers assumed that codeposition of these two metals proceeds by the induced co-deposition mechanism $[11,16]$. Several works were devoted to the study of morphology and phase composition of Ni-Mo films [17-20]. X-ray diffraction analysis revealed that Ni-Mo alloys electrodeposited from citrate electrolyte (pH 8.5-9.5) contain Ni-Mo solid solution. Clear diffraction peaks were observed for films having 12-30 wt.\% of Mo, being more intensive at decreased (down to $12 \mathrm{wt} . \%$ ) content of molybdenum in deposits [17]. It was also found that Ni-Mo deposit is a solid solution with grain sizes ranging from 4 to $17 \mathrm{~nm}$ (average size of $5 \mathrm{~nm}$ ), i.e. the electrodeposited Ni-Mo alloy is almost amorphous. A similar conclusion was given after XRD analysis of $\mathrm{Ni}$-Mo alloys electrodeposited from pyrophosphateammonium chloride electrolyte $(\mathrm{pH}$ 8.5) [18]. The results of the energy-dispersive X-ray spectroscopy were firstly demonstrated in $[19,20]$, according to which, electrodeposited Ni-Mo alloys with high Mo content contain up to $\sim 50$ at.\% of oxygen. A significant atomic percentage of oxygen (3050 at.\%) was also found during the co-deposition of nickel and molybdenum in all electrodeposited samples [21,22]. During calculation of the composition of Ni-Mo alloy, authors usually considered only the percentage of main components of $\mathrm{Ni}$ and $\mathrm{Mo}$, neglecting the oxygen content in deposits. It was concluded that alloys containing a large amount of Mo are mixtures of $\mathrm{Ni}$ and some polyvalent oxides of Mo (IV) or Mo (VI).

All heretofore presented works devoted to the electrochemical synthesis of Ni-Mo alloys, however, are unsuccessful about obtaining thin films with molybdenum content higher than 30 at.\% and also, corrosion resistances of the obtained alloys are not high enough. The present contribution is devoted to the study of the co-deposition process of nickel and molybdenum from alkaline electrolytes, carried out by taking cyclic and linear polarization curves. Prepared electrolytes and conditions of electrolysis allowed deposition of films with a molybdenum content up to 50.9 at.\%. 


\section{Experimental}

In the study of co-deposition of nickel and molybdenum, $\mathrm{NiSO}_{4} \cdot 7 \mathrm{H}_{2} \mathrm{O}$ of the Indian Central Drug House $(p)$ Ltd. company was used as a source of nickel ions, and $\mathrm{Na}_{2} \mathrm{MoO}_{4} \cdot 2 \mathrm{H}_{2} \mathrm{O}$ of the Indian firm Qualikems Fine Chem Pvt. Ltd. was applied as a source of molybdenum ions. Both salts were dissolved in $\mathrm{NH}_{4} \mathrm{OH}$ of the Indian firm Qualikems Fine Chem Pvt. Ltd., boric acid (CDH Ltd) was added to the electrolyte as a buffering agent, and $\mathrm{NiCl}_{2} \cdot 6 \mathrm{H}_{2} \mathrm{O}(\mathrm{CDH} \mathrm{Ltd})$ was introduced into the electrolyte to reduce the formation of metal oxides. $\mathrm{pH}$ of all electrolyte solutions was 11.2. Except pure ammonia electrolyte solution containing $0.1 \mathrm{M} \mathrm{H}_{3} \mathrm{BO}_{3}+7 \mathrm{M} \mathrm{NH} \mathrm{H}_{4} \mathrm{OH}$, the following alkaline electrolyte solutions for individual deposition of $\mathrm{Ni}, \mathrm{Mo}$ and co-deposition of $\mathrm{Ni}$-Mo were prepared:

1) $0.107 \mathrm{M} \mathrm{NiSO}_{4} \cdot 7 \mathrm{H}_{2} \mathrm{O}+0.13 \mathrm{M} \mathrm{NiCl}_{2} \cdot 6 \mathrm{H}_{2} \mathrm{O}+0.1 \mathrm{M} \mathrm{H}_{3} \mathrm{BO}_{3}+7 \mathrm{M} \mathrm{NH}_{4} \mathrm{OH}$.

2) $0.124 \mathrm{M} \mathrm{Na}_{2} \mathrm{MoO}_{4} \cdot 2 \mathrm{H}_{2} \mathrm{O}+0.1 \mathrm{M} \mathrm{H}_{3} \mathrm{BO}_{3}+7 \mathrm{M} \mathrm{NH}_{4} \mathrm{OH}$.

3) $0.107 \mathrm{M} \mathrm{NiSO}_{4} \cdot 7 \mathrm{H}_{2} \mathrm{O}+0.124 \mathrm{M} \mathrm{Na}_{2} \mathrm{MoO}_{4} \cdot 2 \mathrm{H}_{2} \mathrm{O}+0.13 \mathrm{M} \mathrm{NiCl}_{2} \cdot 6 \mathrm{H}_{2} \mathrm{O}+0.1 \mathrm{M} \mathrm{H}_{3} \mathrm{BO}_{3}+7 \mathrm{M} \mathrm{NH}_{4} \mathrm{OH}$.

For some experiments, the concentrations of $\mathrm{Na}_{2} \mathrm{MoO}_{4} \cdot 2 \mathrm{H}_{2} \mathrm{O}$ in the alkaline electrolyte solution 3) were changed between 0.057 and $0.138 \mathrm{M}$.

Cyclic and linear polarization curves were recorded on IVIUMSTAT Electrochemical interface potentiostat, using a classic three-electrode cell with a capacity of $100 \mathrm{ml}$, and equipped with a water jacket. Platinum wires with an area of $0.2 \mathrm{~cm}^{2}$ and $0.4 \mathrm{~cm}^{2}$, were used as working electrodes, and platinum plate with an area of $4 \mathrm{~cm}^{2}$ as the auxiliary electrode. Silver/silver chloride $(\mathrm{Ag} / \mathrm{AgCl})$ electrode was applied as the reference electrode and all potentials were given relative to this electrode.

To study the properties of deposited films by scanning electron microscopy (SEM) and energy dispersive $X$-ray analysis (EDS) methods on a D2 Phaser from Bruker (Cu Ka; Ni filter) were used. For these experiments, deposition of Ni-Mo film from the corresponding electrolyte solution was carried out on Ni cathode by the galvanostatic method at $25^{\circ} \mathrm{C}$. The current density of $25 \mathrm{~mA} / \mathrm{cm}^{2}$ for 15 hours was applied to the cell, where platinum plate served as the anode. The deposited $\mathrm{Ni}$ Mo film was annealed in air at $500{ }^{\circ} \mathrm{C}$ for 1 hour.

\section{Results and discussion}

Open circuit potential value of the platinum electrode in ammonia electrolyte containing complex nickel compounds was, depending on the concentration of $\mathrm{NiSO}_{4} \cdot 7 \mathrm{H}_{2} \mathrm{O}$ in the electrolyte, recorded between $0.2 \mathrm{~V}$ and $0.4 \mathrm{~V}$ vs. $\mathrm{Ag} / \mathrm{AgCl}$. The first traces of nickel on platinum electrode appear at the potential of $-0.08 \mathrm{~V}$. At the other side, the open circuit potential value of molybdenum in ammonia solution fluctuates, depending on the concentration of $\mathrm{Na}_{2} \mathrm{MoO}_{4} \cdot 2 \mathrm{H}_{2} \mathrm{O}$, between 0.50 and $0.56 \mathrm{~V}$. The deposition of molybdenum oxide occurs at small polarization of $0.04 \mathrm{~V}$, while its first traces appear on the surface of the electrode at the potential of $-0.06 \mathrm{~V}$. The peak of the polarization curve during the deposition of Mo corresponds to the potential of $-0.25 \mathrm{~V}$. It can be stated that in the ammonia electrolyte, deposition potentials of nickel and molybdenum are quite close each to other. Polarization curves of the deposition of nickel, molybdenum, and co-deposition of nickel with molybdenum on Pt electrode from corresponding alkaline electrolytes are presented in Figure 1(a). For the comparison purpose, the polarization curve of Pt electrode in pure ammonia electrolyte is presented in Figure 1(b).

It can be seen from Figure 1(a) that the co-deposition of nickel with molybdenum occurs at a potential remarkably close to both, nickel and molybdenum deposition potential values. Also, the cathodic polarization curve of co-deposition of Ni-Mo alloy (curve 3) is placed between polarization curve of nickel (curve 1) and molybdenum (curve 2) deposition. As already known, such an arran- 
gement of polarization curves indicates formation of a solid solution between alloy components [23]. At the potentials -0.75 and $-0.79 \mathrm{~V}$ on curves 3 and 2 , respectively, hydrogen evolution occurs in two stages. The presence of both metals in the composition of the deposited film was confirmed by chemical analysis and data obtained by scanning electron microscope (SEM) discussed below.
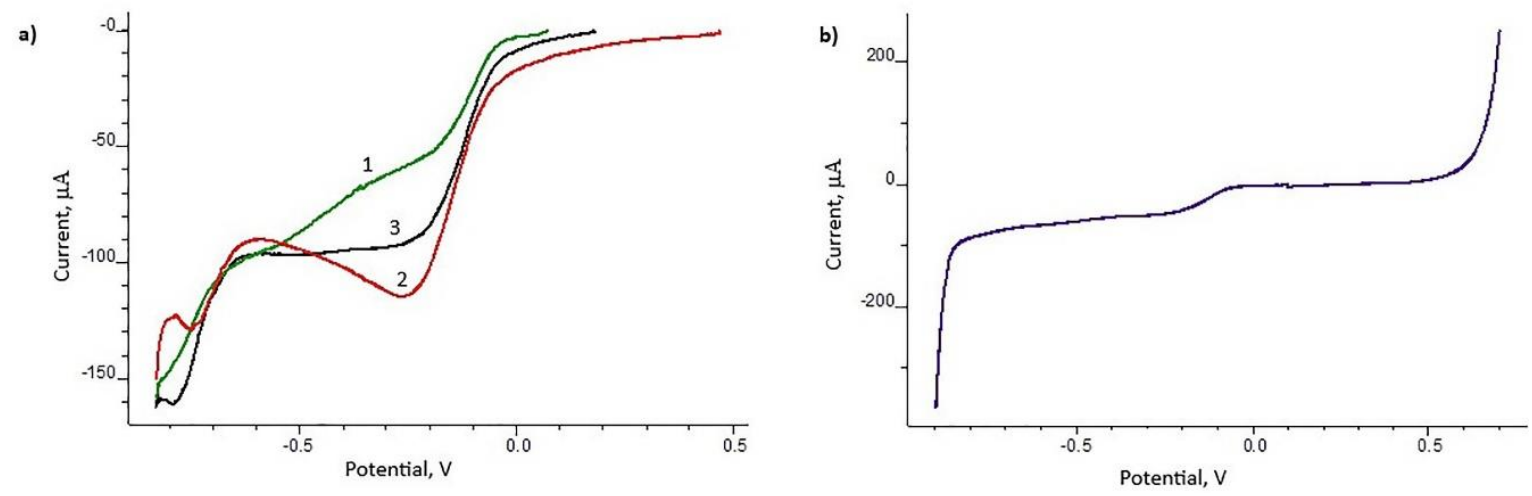

Figure 1. Linear polarization curves $(40 \mathrm{mV} / \mathrm{s})$ of Pt electrode for: a) $\mathrm{Ni}^{2+}$ reduction from electrolyte solution 1) (curve 1), $\mathrm{Mo}^{6+}$ reduction from electrolyte solution 2) (curve 2), co-deposition of $\mathrm{Ni}^{2+}$ with $\mathrm{Mo}^{6+}$ from electrolyte solution 3) (curve 3), and b) pure ammonia electrolyte.

Cyclic voltammetry (CV) curve of co-deposition of nickel and molybdenum from the alkaline electrolyte solution 3 ) is, together with $\mathrm{CV}$ response of Pt electrode in pure ammonia electrolyte, presented in Figure 2. It is obvious that CV of co-deposition has two main sections. The first section corresponds to the co-deposition of nickel and molybdenum, which occurs at the potential of $-0.28 \mathrm{~V}$. When the potential reaches -0.8 to $-0.9 \mathrm{~V}$, hydrogen evolution occurs in two stages, which is indicated by formation of peaks on the cathodic polarization curve at -0.81 and $-0.87 \mathrm{~V}$, respectively. On the anodic sweeping curve, two small plateaus appear on the anodic curve at potentials -0.11 and $0.22 \mathrm{~V}$, respectively. The first plateau corresponds most likely to the anodic dissolution of the deposited film, while the second plateau can be associated with the dissolution of nickel, present as a separate phase in Ni-Mo thin film. Presence of Ni was confirmed by X-ray phase analysis.

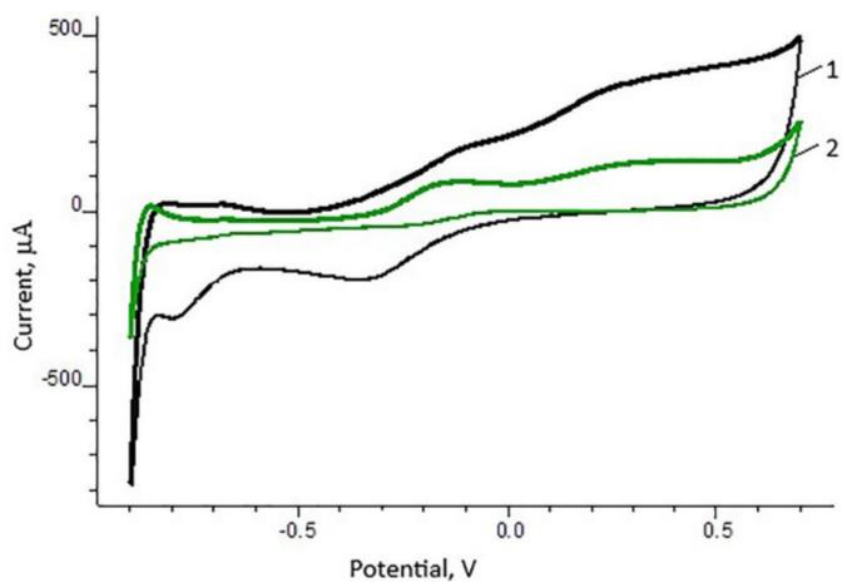

Figure 2. Cyclic voltammetry curve $(100 \mathrm{mV} / \mathrm{s})$ of Pt electrode for co-deposition of Ni and Mo from electrolyte solution 3) (curve 1) and pure ammonia electrolyte (curve 2).

In order to accurately determine processes occurring on the cathodic surface during co-deposition of nickel and molybdenum, the potential of inversion from cathodic to anodic direction was set at either $-0.28 \mathrm{~V}$ or $-0.8 \mathrm{~V}$. Firstly, the cathodic polarization curve was scanned down to the potential value of $-0.28 \mathrm{~V}$, then the process was stopped and after 5 minutes the anodic curve was taken. Figure $3(\mathrm{a})$ shows that at the potential of $0.26 \mathrm{~V}$, a plateau appears on the anodic curve, which corresponds 
to the dissolution of thin Ni-Mo film. If, however, the cathodic scan was stopped at $-0.87 \mathrm{~V}, \mathrm{CV}$ presented in Figure $3(\mathrm{~b})$ shows that no peaks are displayed on the anodic curve before oxygen evolution emerged at $\sim 0.7 \mathrm{~V}$. This suggests that at -0.81 and $-0.87 \mathrm{~V}$ mainly hydrogen is released.
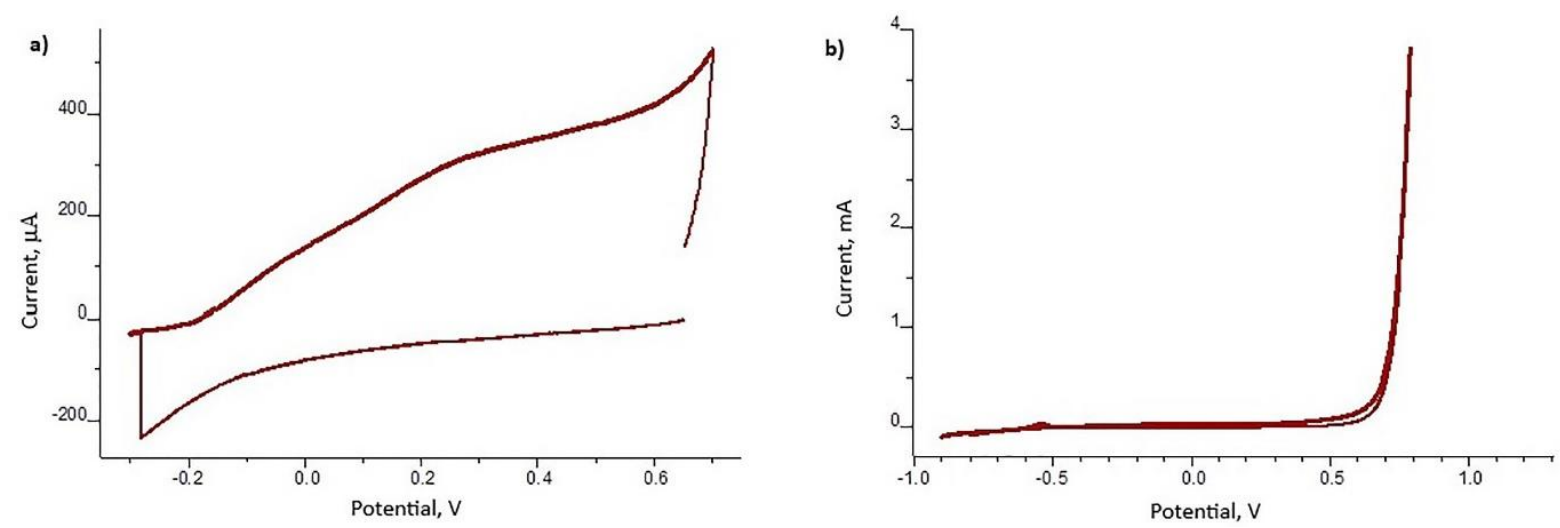

Figure 3. Anodic polarization curves (100 mV/s) of Pt electrode in electrolyte solution 3), after being kept for 5 minutes at negative potential limit of: (a) $-0.28 \mathrm{~V}$, (b) $-0.8 \mathrm{~V}$.

As already known, at metals (Me) in alkaline solutions, hydrogen evolution occurs in two steps according to the following reactions $[24,25]$ :

$$
\begin{aligned}
& \mathrm{Me}\left(\mathrm{H}_{2} \mathrm{O}\right)+\mathrm{e}^{-} \rightarrow \mathrm{Me}(\mathrm{H})+\mathrm{OH}^{-} \\
& \mathrm{Me}(\mathrm{H})+\mathrm{Me}(\mathrm{H}) \rightarrow 2 \mathrm{Me}+\mathrm{H}_{2}
\end{aligned}
$$

The first step (1) describes formation of adsorbed hydrogen, $\mathrm{Me}(\mathrm{H})$, at a metal surface. The second step (2) of the hydrogen evolution reaction can alternatively proceed according to another mechanism:

$$
\mathrm{Me}(\mathrm{H})+\mathrm{H}_{2} \mathrm{O}+\mathrm{e}^{-} \rightarrow \mathrm{Me}+\mathrm{H}_{2}+\mathrm{OH}^{-}
$$

In Figure 4, cathodic potentiodynamic polarization curves of co-deposition of nickel and molybdenum are given for various concentrations of molybdenum ions and concentrations of remaining ions kept constant. An increase in the concentration of $\mathrm{Na}_{2} \mathrm{MoO}_{4} \cdot 2 \mathrm{H}_{2} \mathrm{O}$ leads to a rise in the peak height corresponding to the alloy formation. Deposition of elements to the alloy film occurs at the potential of $\sim-0.32 \mathrm{~V}$.

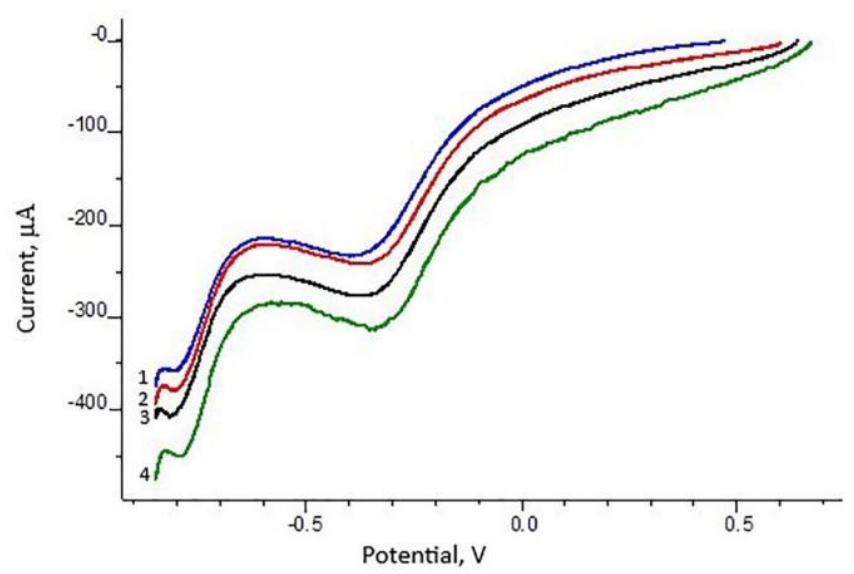

Figure 4. Cathodic polarization curves $(100 \mathrm{mV} / \mathrm{s})$ of Pt electrode for co-deposition of Ni and Mo at various concentrations of $\mathrm{Na}_{2} \mathrm{MoO}_{4} \cdot 2 \mathrm{H}_{2} \mathrm{O}$ in electrolyte solution 3): $0.057 \mathrm{M}$ (curve 1), $0.069 \mathrm{M}$ (curve 2), $0.092 \mathrm{M}$ (curve 3), $0.138 \mathrm{M}$ (curve 4).

The mechanism of the release of molybdenum is reported in [26], according to which, a thin film composed of a mixture of trivalent molybdenum and bivalent nickel hydroxides is formed on the 
cathode. Presence of metal-hydroxide depositor provides the necessary permeability of the film, so that molybdenum ions can penetrate to the cathode and can be deposited on it. At the same time, the film protects released molybdenum atoms from reverse oxidation with electrolyte. Other researchers believe that co-deposition of Mo with other metals occurs in two stages. During the first stage (slow), molybdenum oxide $\left(\mathrm{MoO}_{2}\right)$ transforms into a mixed oxide $\left(\mathrm{MoO}_{2} \mathrm{Ni}_{4}\right)$ by the following reaction:

$4 \mathrm{MoO}_{2}+4 \mathrm{Ni}^{2+}+8 \mathrm{e}^{-}=4 \mathrm{MoO}_{2} \mathrm{Ni}_{4}$

During this slow reaction, the mixed oxide forms a compound on the surface that inhibits hydrogen evolution [27]. Then, the mixed oxide is electrochemically reduced with the participation of nickel ions to form $\mathrm{Ni}_{3} \mathrm{Mo}$ alloy:

$$
\mathrm{MoO}_{4}^{2-}+3 \mathrm{Ni}^{2+}+8 \mathrm{e}^{-}+(4+\mathrm{n}) \mathrm{H}=\mathrm{Ni}_{3} \mathrm{Mo}+4 \mathrm{OH}^{-}+\mathrm{nH}_{\text {ads }}
$$

Reaction (4), proceeding slowly in combination with a relatively fast reaction (5) can be the main reaction in the co-deposition of nickel with molybdenum to form $\mathrm{Ni}_{3} \mathrm{Mo}$ alloy.

Ernest and Holt [28] proposed a two-stage mechanism of the co-deposition of Mo with other metals $(M)$, the mechanism of which can be depicted as follows:

$$
\begin{aligned}
& \mathrm{MoO}_{4}{ }^{2-}+4 \mathrm{H}_{2} \mathrm{O}+\mathrm{ne}^{-}=\mathrm{Mo}(\mathrm{OH})_{(6-n)}+(2+n) \mathrm{OH}^{-} \\
& \mathrm{Mo}(\mathrm{OH})_{(6-n)}+(6-n) \mathrm{H}+\mathrm{M}=\mathrm{M} \cdot \mathrm{Mo}+(6-n) \mathrm{H}_{2} \mathrm{O}
\end{aligned}
$$

It is known that in strongly alkaline solutions, molybdenum is in the form of monomolybdate ions $\left[\mathrm{MoO}_{4}\right]^{2-}$ and at high concentrations of molybdenum, only a small part of molybdate ions reaching the cathode surface is reduced to the metallic Mo. The rest is deposited in the form of multivalent oxides, most of which is $\mathrm{MoO}_{2}$ [29]. In the co-deposition of $\mathrm{Ni}$ with Mo, molybdate ions are electrochemically reduced to $\mathrm{MoO}_{2}$ according to the following reaction:

$$
\mathrm{MoO}_{4}{ }^{2-}+2 \mathrm{H}_{2} \mathrm{O}+2 \mathrm{e}^{-}=\mathrm{MoO}_{2}+4 \mathrm{OH}^{-}
$$

Due to the fact that $\mathrm{MoO}_{2}$ has catalytic properties in the reaction of hydrogen evolution, the chemical reduction of molybdenum by atomic hydrogen occurs at the cathode, followed by adsorption of Mo on nickel electrode with the formation of induced Ni-Mo alloy [30].

Figure 5 shows the results of X-ray phase analysis of thin Ni-Mo films deposited on Ni substrate by the galvanostatic method at $i_{\mathrm{k}}=25 \mathrm{~mA} / \mathrm{cm}^{2}$ for 15 hours. Whereas fresh deposit didn't show resolvable diffraction pattern, after annealing in air at $500^{\circ} \mathrm{C}$ for 1 hour, the X-ray diffraction pattern shows clear peaks corresponding to $\mathrm{Ni}, \mathrm{MoO}_{3}$, and $\mathrm{NiMoO}_{4}$. The appearance of peaks corresponding to $\mathrm{NiMoO}_{4}$ phase further confirms that $\mathrm{NiMoO}_{4}$ phase is formed due to presence of already formed $\mathrm{MoO}_{2}$ phase. Apparently, the co-deposition of nickel with molybdenum occurs through the stage of formation of oxides of these metals, as a result of which a solid solution is formed. When the films are annealed at $500{ }^{\circ} \mathrm{C}$ for 1 hour, a solid-phase reaction occurs between nickel oxides and molybdenum oxides, resulting in the formation of $\mathrm{NiMoO}_{4}$ phase, seen in the X-ray diffractogram shown in Figure 5 . The $\mathrm{MoO}_{3}$ phase, however, is most likely formed as a result of induced deposition from molybdate ions according to the following reaction:

$$
\mathrm{MoO}_{4}{ }^{2-}+\mathrm{Ni}^{2+}+\mathrm{H}_{2} \mathrm{O}+2 \mathrm{e}^{-} \rightarrow \mathrm{MoO}_{3}+\mathrm{Ni}+2 \mathrm{OH}^{-}
$$

It should be noted that formation of $\mathrm{NiMoO}_{4}$ phase which contributes to high catalytic activity of $\mathrm{Ni}-\mathrm{Mo}$ alloys, was already obtained as a result of double annealing for the first time for 5 hours at 300 and again at $600^{\circ} \mathrm{C}$ for another 5 hours [22]. In our study, this compound appears in the diffraction pattern upon annealing for 1 hour at $500^{\circ} \mathrm{C}$. Induced co-deposition is accompanied by the evolution of hydrogen, but part of the current consumed in this process is so small that can be neglected. 


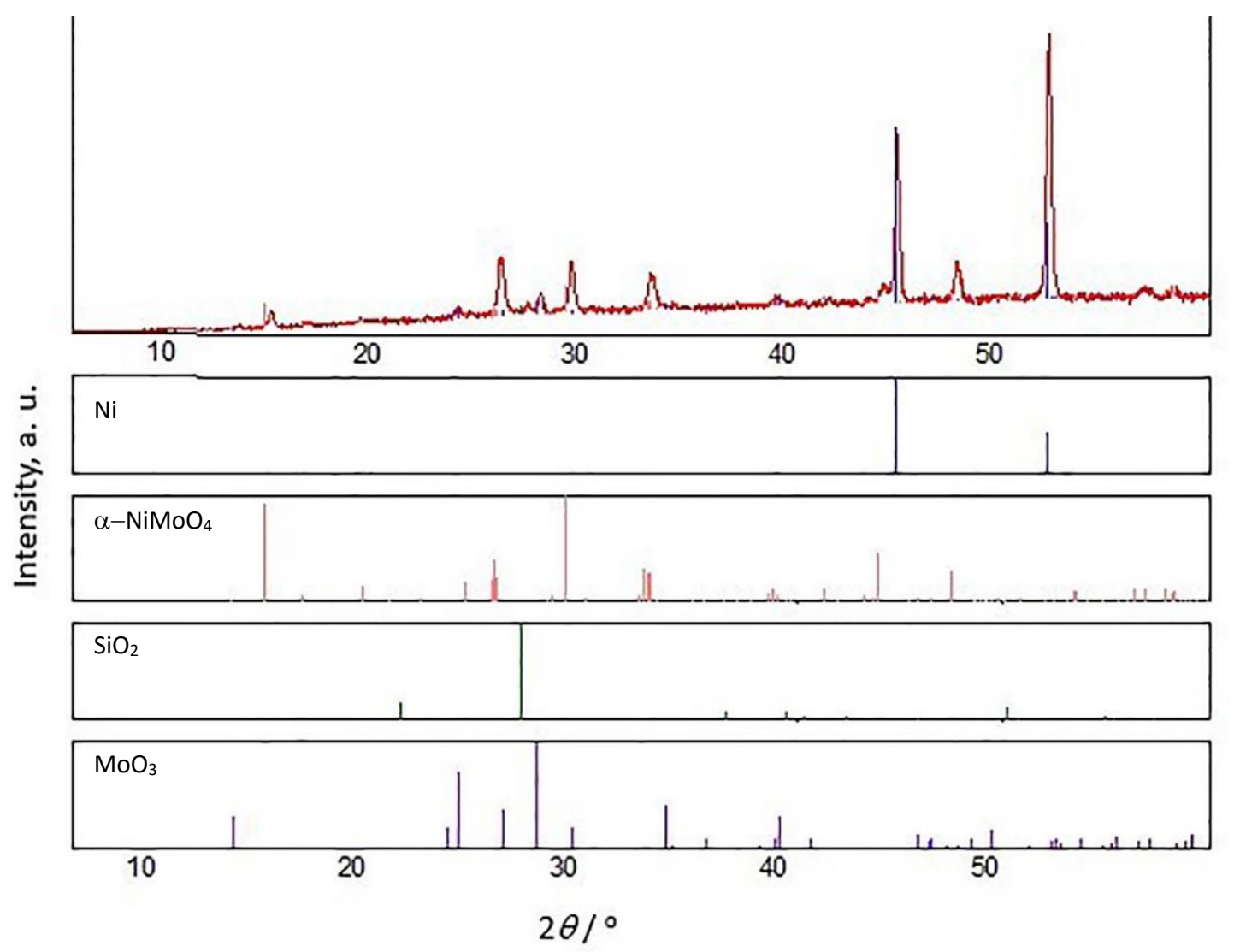

Figure 5. X-ray diffraction pattern of Ni-Mo deposit annealed at $500{ }^{\circ} \mathrm{C}$ for 1 hour. Co-deposition of Ni with Mo was performed on Ni electrode from electrolyte solution 3) at $i_{k}=25 \mathrm{~mA} / \mathrm{cm}^{2}$ for 15 hours.

Figure 6 shows cyclic voltammograms of co-deposition of $\mathrm{Ni}$ with $\mathrm{Mo}$ as a function of the potential scan rate. These curves can be divided into two groups. The first group, represents the curves recorded at potential scan rates from 10 to $20 \mathrm{mV} / \mathrm{s}$ (curves 5 and 6), while the second group consists of curves recorded at scan rates of $40 \mathrm{mV} / \mathrm{s}$ and higher (curves 1-4).

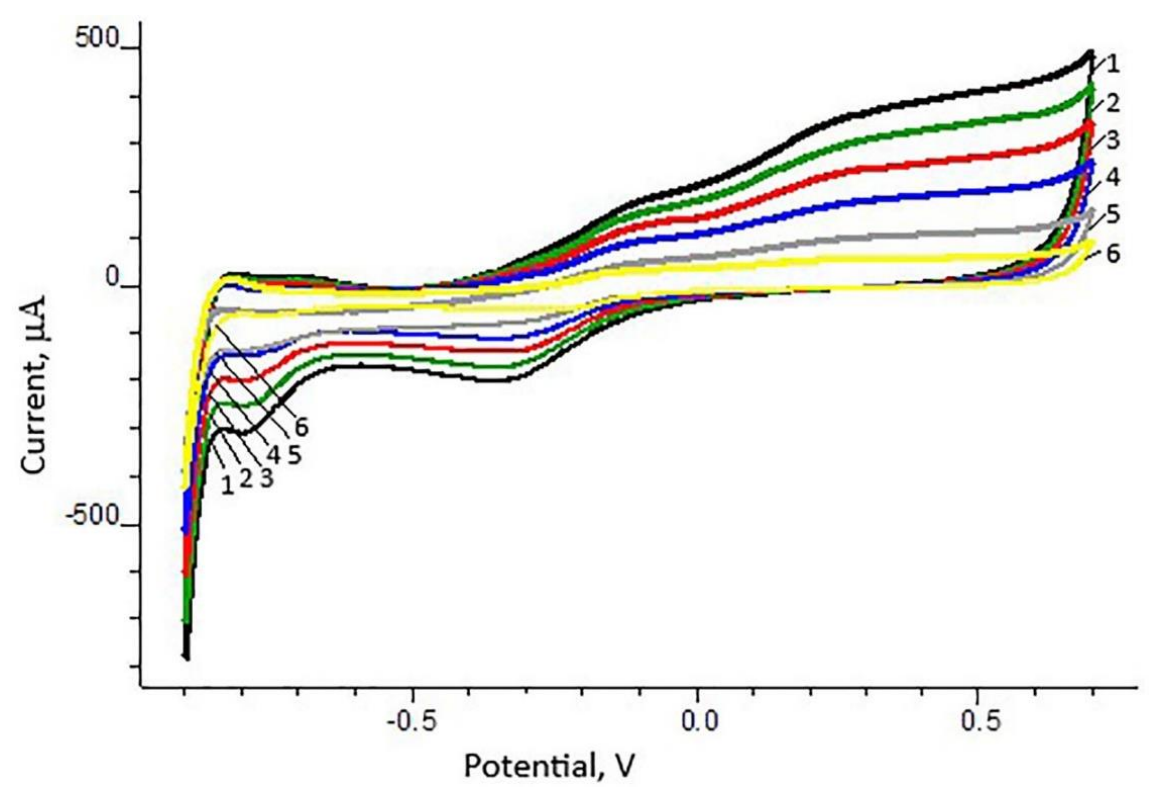

Figure 6. Cyclic voltammograms of Pt electrode for co-deposition of Ni with Mo from alkaline electrolyte solution 3) at various potential scan rates (mV/s): 100 (curve 1), 80 (curve 2), 60 (curve 3), 40 (curve 4), 20 (curve 5), 10 (curve 6). 
On the curves belonging to the first group, only one peak followed by a plateau appears on the anode component at the potential of $-0.13 \mathrm{~V}$, corresponding to the dissolution of a thin Ni-Mo film. At potential scan rates above $40 \mathrm{mV} / \mathrm{s}$, another peak followed by new plateau appears at the potential of $0.23 \mathrm{~V}$. It is quite probable that at $0.23 \mathrm{~V}$ nickel dissolves and enters to the alloy as a separate phase, which is confirmed by $\mathrm{X}$-ray phase analysis shown in Figure 5.

Morphologies and chemical compositions of fresh and annealed Ni-Mo film deposited on $\mathrm{Ni}$ electrode are presented in Figure 7.
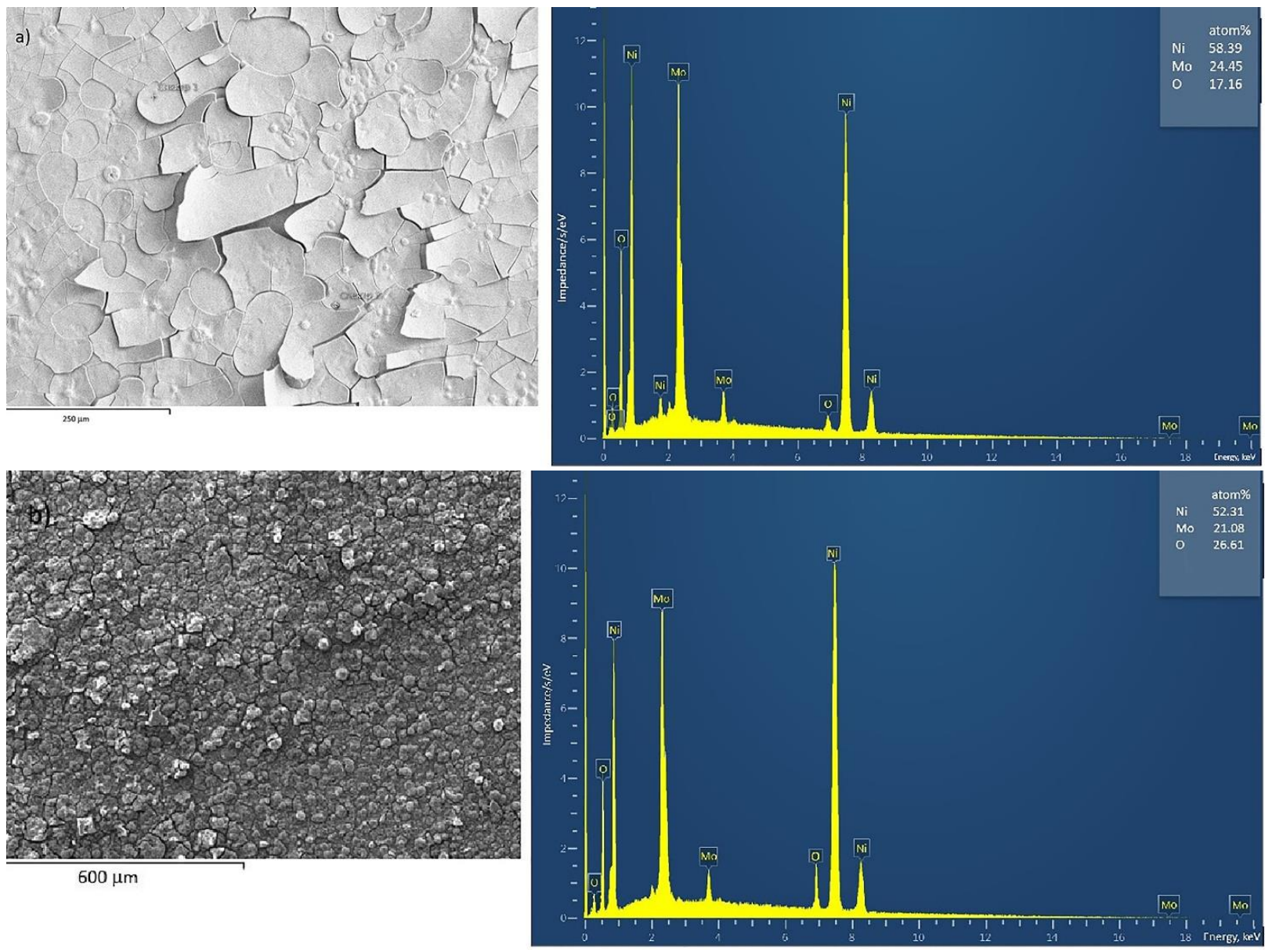

Figure 7. Morphology and composition of thin Ni-Mo film deposited on Ni electrode under conditions described in Fig. 5: (a) not subjected to annealing, (b) annealed at $500{ }^{\circ} \mathrm{C}$ for 1 hour.

According to Figure 7(a), the freshly deposited, i.e. not annealed film consists of 58.39 at.\% nickel, 24.45 at.\% molybdenum, and 17.16 at.\% oxygen. Surface image of the sample shows that Ni-Mo deposit is amorphous and composed of small particles. This was a reason why the XRD pattern of this deposit did not yield any consistent results. Comparison of Figure 7(a) and (b) shows that for the films subjected to annealing, the particle size was increased as a result of sintering at high temperatures. Also, some nickel peaks disappeared or decreased, the molybdenum content also decreased, and the oxygen content increased. The composition of the films changes insignificantly after annealing and consists of 52.31 at.\% nickel, 21.08 at.\% molybdenum, and 26.61 at.\% oxygen. In all cases, atmospheric oxygen also participates in the reaction, which leads to an increase in the amount of oxygen after annealing and decrease in the content of molybdenum and nickel in the deposits, what agrees well with literature data $[22,31]$.

Figure 8 shows linear polarization curves of Pt electrode for co-deposition of $\mathrm{Ni}$ with $\mathrm{Mo}$ as a function of the potential scan rate $(v)$. Based on the data in Figure 8 , the dependence of limiting 
current $\left(i_{L}\right)$ on $v^{0.5}$ was plotted and shown in Figure 9. The rectilinear dependence occurs when the deposition rate is controlled by diffusion of ions to the cathode surface [32]. These data are in good agreement with data obtained in $[21,22,33,34]$.

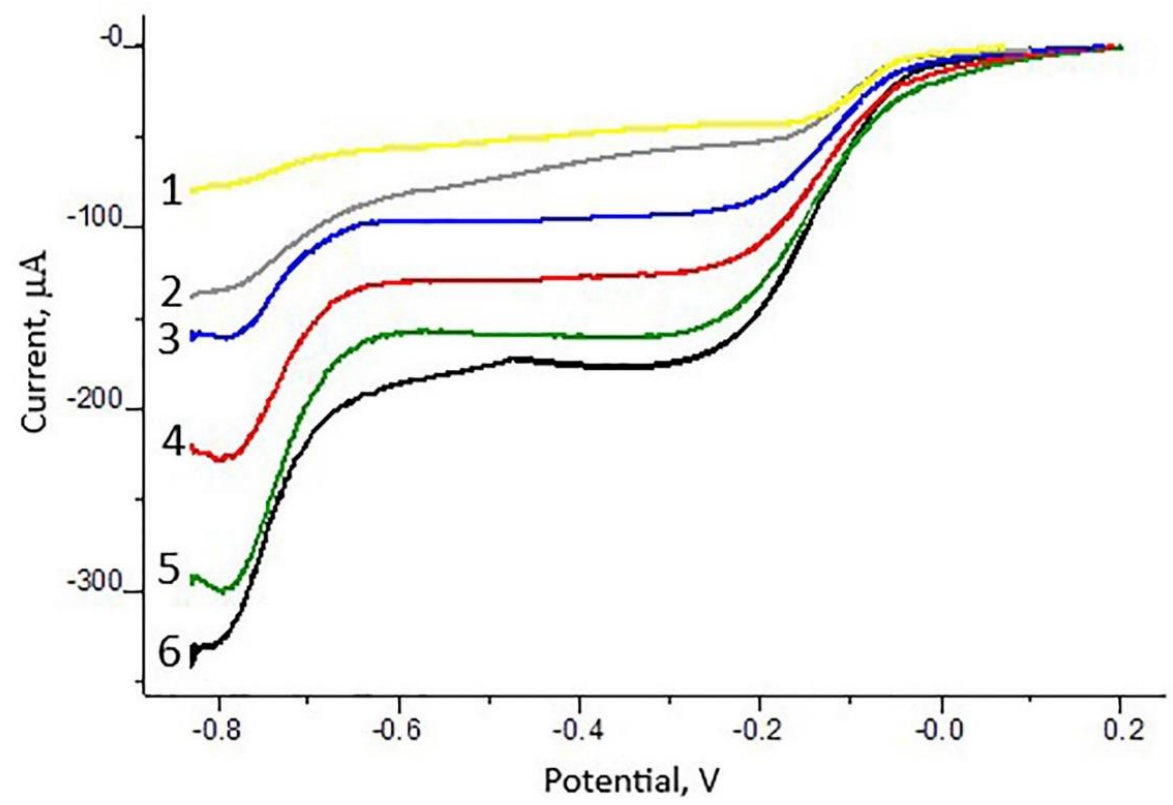

Figure 8. Linear cathodic polarization curves of Pt electrode for co-deposition of Ni with Mo from electrolyte solution 3) at various scan rates (mV/s): 10 (curve 1), 20 (curve 2), 40 (curve 3), 60 (curve 4), 80 (curve 5), 100 (curve 6).

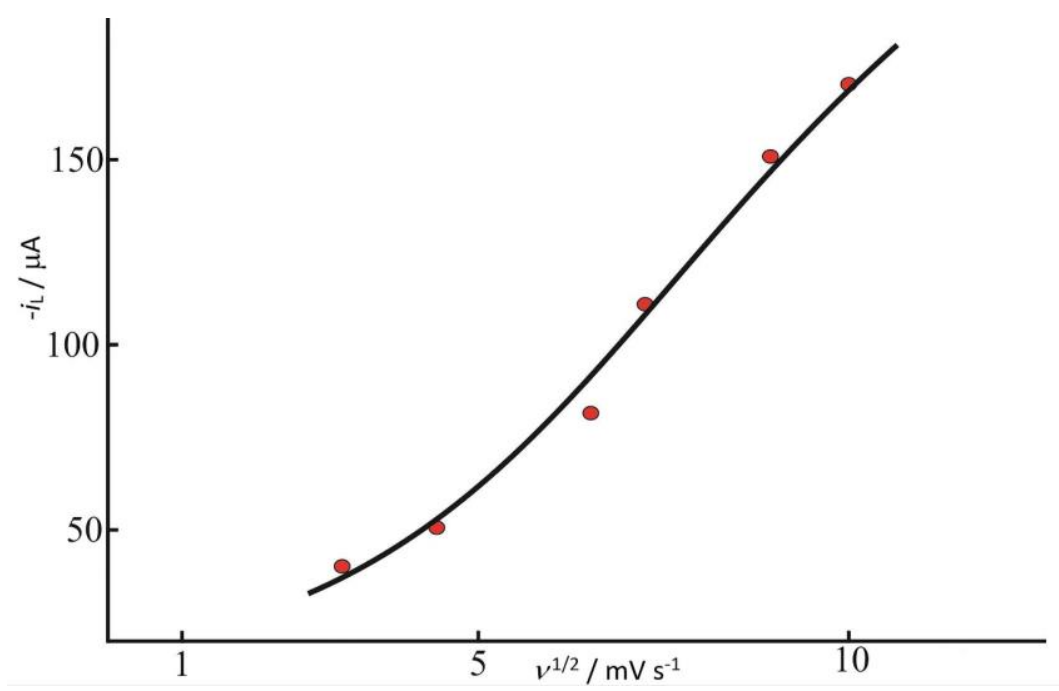

Figure 9. Dependence of $i_{L}$ on $v^{1 / 2}$ for data taken from Fig. 8.

\section{Conclusions}

It was found that during co-deposition of nickel with molybdenum, a solid solution of these two metals is formed, and the deposited alloys are amorphous. Co-deposition passes through the stage of formation of oxides of these two metals. Annealing at $500{ }^{\circ} \mathrm{C}$ for one hour makes sample polycrystalline and $\mathrm{NiMoO}_{4}$ compound appeared in the X-ray diffraction pattern. The process of co-deposition is controlled by diffusion of ions to the cathodic surface. The knowledge of the mechanism of codeposition of nickel with molybdenum will make it possible to select optimal conditions for the deposition of alloys of strictly required composition with satisfactory electrocatalytic properties.

The catalytic activity of amorphous Ni-Mo film is higher than film subjected to annealing, what is due to the large real surface of amorphous films. 


\section{References}

[1] B. E. Conway, L. Bai, M. A. Sattar, International Journal of Hydrogen Energy 12(9) (1987) 607-621 https://dx.doi.org/10.1016/0360-3199(87)90002-4.

[2] J. M. Jakšić, M. V. Vojnović, N. V. Krstajić, Electrochimica Acta 45(25-26) (2000) 4151-4158 https://dx.doi.org/10.1016/S0013-4686(00)00549-1.

[3] A. Sh. Aliyev, R. G. Guseynova, U. M. Gurbanova, D. M. Babanly, V. N. Fateev, J. V. Pushkareva, D. B.Tagiyev, Chemical Problems 16(3) (2018) 283-306 https://dx.doi.org/10.32737 / 2221-8688-20183-283-306.

[4] P. Kedzierzawski, D. Oleszak, M. Janik-Czachor, Materials Science and Engineering: A 300(1-2) (2001) 105-112 https://dx.doi.org/10.1016/S0921-5093(00)01672-5.

[5] S. D. De la Torre, D. Oleszak, A. Kakitsuji, K. Miyamoto, H. Miyamoto, S. R. Martinez, C. F. Almeraya, V. A. Martinez, J. D. Rois, Materials Science and Engineering: A 276(1-2) (2000) 226-235 https://dx.doi.org/10.1016/S0921-5093(99)00156-2.

[6] G. L. Goswami, S. Kumar, R. Galun, B. L. Mordike, Lasers in Engineering 13(1) (2003) 35-44 https://www.researchgate.net/publication/257460030.

[7] V. A. Majidzade, A. Sh. Aliyev, D. M. Babanly, M. Elrouby, D. B.Tagiyev, Acta Chemica Slovenica 66(1) (2019) 155-162 https://dx.doi.org/10.17344/acsi.2018.4733.

[8] U. M. Gurbanova, Azerbaijan Chemical Journal 4 (2019) 59-64 https://dx.doi.org/10.32737/00052531-2019-4-59-64.

[9] J. Aikaitë, O. Gylienë, O. Nivinskienë, Chemija Vilnius 14(3) (2003) 135-139 http://elibrary.lt/resursai/LMA/Chemija/C-135.pdf.

[10] U. M. Gurbanova, Journal of Azerbaijan National Academy of Science Nakhchivan Branch Office 2 (2019) 60-67.

[11] E. J. Podlaha, D. Landolt, Journal of the Electrochemical Society 143(3) (1996) 885-892 https://doi.org/10.1149/1.1836553.

[12] C. Ma, S. C. Wang, F. C. Walsh, Transactions of the IMF 93(2) (2015) 104-112 https://dx.doi.org$\angle 10.1179 / 0020296714 Z .000000000218$

[13] N. Miao, J. Jiang, W. Wu, Journal of Nanomaterials (2018) 1817542. https://dx.doi.org/10.1155/2018/1817542.

[14] N. B. Panah, I. Danaee, M. Payehghadr, A. Madahi, Acta Chemica Slovenica 65(2) (2018) 312-318 https://dx.doi.org/10.17344/acsi.2017.3953.

[15] J. Gustavsson, C. Hummelgård, J. Bäckström, I. O. Wallinder, S. M. H. Rahman, G. Lindbergh, S. Eriksson, A. Cornell, Journal of Electrochemical Science and Engineering 2(3) (2012) 105-120 https://doi.org/10.5599/jese.2012.0015.

[16] E. J. Podlaha, D. Landolt, Journal of the Electrochemical Society 143(3) (1996) 893-899. https://doi.org/10.1149/1.183655

[17] E. Chassaing, N. Portail, A.-F. Levy, G. Wang, Journal of Applied Electrochemistry 34(11) (2004) 10851091 https://dx.doi.org/10.1007/s10800-004-2460-z.

[18] M. Donten, H. Cesiulis, Z. Stojek, Electrochimica Acta 50(6) (2005) 1405-1412 https://dx.doi.org/10.1016/i.electacta.2004.08.028.

[19] L. S. Sanches, S. H. Domingues, A. Carubelli, L. H. Mascaro, Journal of the Brazilian Chemical Society 14(4) (2003) 556-563 https://dx.doi.org/10.1590/S0103-50532003000400011.

[20] L. S. Sanches, S. H. Domingues, C. E. B. Marino, L. H. Mascaro, Electrochemistry Communications 6 (2004) 543-548 https://dx.doi.org/10.1016/i.elecom.2004.04.002.

[21] V. D. Jović, B. M. Jović, G. R. Stafford, N. V. Krstajić, Z. Twardowski, in: SURFIN 2002. Chicago (2002) 76-84.

[22] N. V. Krstajić, L. Gajić-Krstajić, U. Lačnjevac, B. M. Jović, S. Mora, V. D. Jović, International Journal of Hydrogen Energy 36(11) (2011) 6441-6449 https://dx.doi.org/10.1016/j.ijhydene.2011.02.105.

[23] Yu. M. Polukarov, K. M. Qorbunova, Elektroosajdeniye splavov / V. Itoqi nauki. Elektrokhimiya. Elektroosajdeniye metalov i splavov 1 (1968) 259.

[24] A. Lasia, A. Rami, Journal of Electroanalytical Chemistry and Interfacial Electrochemistry 294(1-2) (1990) 123-141 https://dx.doi.org/10.1016/0022-0728(90)87140-F. 
[25] Y. Choquette, L. Brossard, A. Lasia, H. Menard, Journal of the Electrochemical Society 137(6) (1990) 1723-1730 https://doi.org/10.1149/1.2086788.

[26] L. O. Case, A. Kjrohn, Journal of the Electrochemical Society 105(9) (1958) 512-520 https://doi.org/$10.1149 / 1.2428912$.

[27] E. Chassaing, K. Vu Quang, R. Wiart, Journal of Applied Electrochemistry 19(6) (1989) 839-844 https://doi.org/10.1007/BF01007931.

[28] D. W. Ernst, M. L. Holt, Journal of the Electrochemical Society 105(11) (1958) 686-692 https://dx.doi.org/10.1149/1.2428691.

[29] Y. Zeng, Z. Li, M. Ma, S. Zhou, Electrochemistry Communications 2(1) (2000) 36-38 https://dx.doi.org/10.1016/S1388-2481 (99) 00137-X.

[30] E. Beltowska-Lehman, P. Indyka, Thin Solid Films 520(6) (2012) 2046-2051 https://dx.doi.org$\angle 10.1016 /$ j.tsf.2011.10.024.

[31] U. Lačnjevac, B. M. Jović, Z. Baščarević, V. M. Maksimović, V. D. Jović, Electrochimica Acta 54(11) (2009) 3115-3123 https://dx.doi.org/10.1016/j.electacta.2008.11.068.

[32] S. V. Gorbachev, Zhurnal Fizichekoi Khimii 24(7) (1950) 888-896 (in Russian).

[33] V. D. Jović, Zaštita Materijala 52(2) (2011) 95-100.

[34] V. D. Jović, B. M. Jović, U. Lačnjevac, G. Branković, S. Bernik, A. Rečnik, Electrochimica Acta 55(13) (2010) 4188-4193 https://dx.doi.org/10.1016/j.electacta.2010.02.065.

C 2021 by the authors; licensee IAPC, Zagreb, Croatia. This article is an open-access article distributed under the terms and conditions of the Creative Commons Attribution license (https://creativecommons.org/licenses/by/4.0/) 